Article History

Submission: $\quad$ Review:

2019-06-25

Accepted:

2019-01-21

Doi: https://doi.org/10.33367/ijies.v2i1.652

2019-07-02

\title{
Concept Of Educational Values For Tauhid National Education System Perspective
}

\author{
Nurhadi $^{1}$ \\ ${ }^{1}$ Islamic College (STAI) Al-Azhar Pekanbaru Riau Indonesia \\ ${ }^{1} \mathrm{e}$-mail of first author
}

\begin{abstract}
This study aims to 1) know the values of Tawhid Education in the National Education System. 2) knowing the relevance of the National Education System Law No. 20 of 2003 in strengthening the values of Tawhid Education. This type of research is a literature study literature (library research). The primary source of this research uses Law No. 20 of 2003 concerning the National Education System. The research results obtained 1) Tawhid education values contained in Chapter II Article 3, Chapter V Article 12 paragraph 1 point A, Chapter X Article 36 paragraph 3 point A, and 2) Relevance of the National Education System Law No 20 of 2003 to strengthening the values of Tawheed education that the main purpose is: "Faithful and devoted to the Almighty God". Then the right of the first student is to get religious education in accordance with a religion that is followed and taught by religious educators. And the curriculum is arranged in accordance with the level of education within the framework of the Unitary State of the Republic of Indonesia with the first increase, namely faith and piety.
\end{abstract}

Keywords: important or specific word (s) or phrase (s) of the article.

\section{Introduction}

In modern times there are several crises that must be faced by humans, such as the monetary crisis, food crisis, the most important crisis and we should reflect together is a crisis of faith. The crisis of faith is due to lack of spiritual nutrition and lack of Tauhid function in everyday human life this. Most people only prioritize the interests of the world rather than the interests of the hereafter. So that is realized only human characteristics that smell worldly, such as hedonism, lust satisfaction, and so forth. Thus, this is because only a portion of humans can use the function and place the role of Tawhid correctly and in accordance with the conditions of the present human era. In fact, if modern society places Tawhid in its daily life, God willing, a peaceful society will be created. safe, and farthest from despicable characteristics such as corruption, nepotism, fraud, and actions that violate religious law, as well as civil and state criminal law. ${ }^{1}$

In humans there is a dominant element that is very influential for human life in carrying out its duties and position as "Abdullahdan Khalifatullah" on this earth. This potential is simply called fitrah. ${ }^{2}$ In accordance with his nature, Allah created man, which is complemented by religious instincts, namely the religion of Tawheed. If there is

${ }^{1}$ Zainul Bahri, Tawhid Education Program in the National Education System (Postgraduate Thesis of UIN Suska Riau PAI Study Program, 2018), p. 2

${ }^{2}$ Abdul Mujib, Fitrah and Islamic Personality: A Psychological Approach, (Jakarta: Darul Falah, 2009), p. 1. 
someone who is not religious or denies the existence of Allah, it means that he denies his nature or instinct, which then is what is called Fitrah Tauhid. ${ }^{3}$

Facing globalization and the swift influence of technological, information and communication sophistication, Indonesians inevitably have to face cultural globalization, which impacts on the emergence of various national problems, ranging from juvenile delinquency, student brawls, brawls among citizens, drug abuse, pornography, pornoaction free sex, ${ }^{4}$ then when viewed by educational institutions, especially in schools there are still students who steal their friends' school supplies, when the exam is still cheating and carrying small notes to be seen during the exam, lying to the teacher and friends themselves, against to teachers and so on, and the saddest thing is that many of the perpetrators of this action in adolescents are still in the school ladder. ${ }^{5}$ This means that Tawheed education has begun to disappear from someone's personality. So that doing an action that is not in accordance with Islamic shari'a. ${ }^{6}$

The influence of globalization and the sophistication of the sophistication of technology, information and communication has turned out to have created new problems, especially for the world of education. The most crucial is the issue of Tawhid education values. Because of that, one of the fundamental things that is the center of attention is the need for Tawheed education which has recently been eliminated, because education is the process of transalizing internal knowledge and values to students through teaching, habituation, guidance, care, supervision , and the development of its potential, in order to achieve harmony and perfection of life. ${ }^{7}$ Thus it can be understood that education is actually a way of how to humanize humans themselves. So as to achieve happiness of life in the world and in the hereafter. ${ }^{8}$

This is in line with Law No. 20 of 2003 concerning Article 3 of the National Education System, which states that national education aims to develop the potential of students to become human beings who believe and fear the Almighty God, are noble, healthy, knowledgeable, capable, creative , independent, and become a democratic and responsible citizen. ${ }^{9}$

To direct this research so that there is no mistake in conducting research, the authors formulate the problem as follows: 1). What are the Tawhid Education Values in the National Education System Law? 2). What is the relevance of the National Education System Law No. 20 of 2003 in strengthening Tawheed Education Values?

\footnotetext{
${ }^{3}$ Abdul Majid, Tawheed Based Education: Sermon 'Eid Al-Fitr 1 Syawal 1423 H./2012 M.), p. 2

${ }^{4}$ Herimanto, Basic Social and Cultural Sciences, (Jakarta: PT. Bumi Aksara, 2010), p. 78.

${ }^{5}$ Anas Salahuddin and Irwan Alkrienchiechie, Character Education, Education Based on Religion and National Culture, (Bandung: Faithful Library, 2013), p. 30-31.

${ }^{6}$ Zainul Bahri, Tawhid Education Program in the National Education System (Postgraduate Thesis of UIN Suska Riau PAI Study Program, 2018), p. 4

${ }^{7}$ Abdul Mujib and Yusuf Mudzakkir, Islamic Education, (Jakarta: Kencana Prenada Media, 2016), p. $27-28$.

${ }^{8}$ Zainul Bahri, Tawhid Education Program in the National Education System (Postgraduate Thesis of UIN Suska Riau PAI Study Program, 2018), p. 4

${ }^{9}$ National Education Ministry Compilation Team, Republic of Indonesia Law No. 20 of 2003 concerning National Education System, (Bandung: Umbara Image Publishers, 2007), p. 3.
} 


\section{Theoretical Framework}

\section{Tawhid Education Values}

\section{a. Definition of Value}

Some experts formulate the notion of value, according to Rahmat Mulyana, the word value, which is then translated into Indonesian into value, comes from Latin valere or ancient French valoir. The denotative meaning, valere, valence, value, or value can be interpreted as prices. However, when the word has been linked to an object or perceived from a certain point of view, the value contained in it has various interpretations. The difference in interpretation of the price of a birth value is not only caused by differences in human interest in material things or scientific studies, but more than that, the price of a value needs to be articulated to realize and utilize the meanings of life. ${ }^{10}$ Understanding the meaning of values in terms of terminology according to Rahmat Mulyana is also influenced by the perspective and scientific knowledge of a person. According to Gordon Allport, a personality psychologist defines that "value is a belief that makes a person act on the basis of his choice." Like psychologists in general, belief is placed as a higher psychological area than other regions such as desires, motives, attitudes, desires, and needs. Therefore, decisions are wrong, both bad in this area are the result of a series of psychological processes which then direct individuals to actions and actions that are in accordance with the value of their choice. ${ }^{11}$ Another definition of value is a picture of something beautiful and attractive, which is fascinating, amazing, makes us happy, happy and is something that makes someone or a group of people want to have it. ${ }^{12}$

Whereas according to Chabib Thoha, value is a trait that is inherent in something (belief system) that has been associated with a subject that gives meaning (humans who believe). ${ }^{13}$ And according to Sidi Gazalba, who was quoted as saying Thoha meant that value as something abstract, not concrete, not fact, and not only limited to right and wrong, but appreciation that is desired and unwanted. ${ }^{14}$ From some of the opinions of experts on value, it can be concluded that value is something valuable, useful, and beautiful to enrich the heart and make people aware of their dignity and dignity. Value comes from the heart which functions to encourage and direct humans. ${ }^{15}$

Thus a value that is considered important, both to be used as a reference and symbolizes quality which is then given weight both by individuals and groups. In general, the scope of the definition of value is unlimited, meaning that everything in this universe is of value. Muhammad Noor Syam quotes from Briatnica Encyclopedia: he states that value is a type of appreciation or interest. While according to idealism, value is a normative and objective generally accepted. This means that attitudes, behavior and feelings of expression also have a relationship with good and bad quality. ${ }^{16}$

\footnotetext{
${ }^{10}$ Rahmat Mulyana, Articulating Value Education, (Bandung: Al-Fabeta, 2011), p. 7.

${ }^{11}$ Rahmat Mulyana, Articulating Value Education, p. 9.

${ }^{12}$ Muhmidayeli, Educational Philosophy, (Bandung: PT Refika Aditama, cet. 2nd, 2013), p. 101.

${ }^{13}$ Thoha, HM. Chabib, Kapita Selekta Islamic Education, (Yogyakarta: Student Library, 2006), p.

18.

${ }^{14}$ Thoha, HM. Chabib, Kapita Selekta Islamic Education, p. 61.

${ }^{15}$ Zainul Bahri, Tawhid Education Program in the National Education System (Postgraduate Thesis of UIN Suska Riau PAI Study Program, 2018), p. 12

${ }^{16}$ Zainul Bahri, Tawhid Education Program in the National Education System, p. 13 Indonesian Journal of Islamic Education Studies (IJIES)

Volume 2, Nomor 1, Juni 2019
} 


\section{b. Understanding Tawheed Education}

Education, according to the large Indonesian dictionary the word education originates from the word "educate" and gets the suffix "pe" and the suffix "an", then this word means the process, method or action of educating. Thus education means the process of changing attitudes and behavior of a person or group of people in an effort to mature people through teaching and training efforts. ${ }^{17}$

Whereas according to experts the other words of education ${ }^{18}$ are often used to translate the word "education" in English. ${ }^{19}$ In terms of there are several meanings according to education experts. Azyumardi Azra argues that education is a process of preparing young people to run their lives and fulfill their life goals more effectively and efficiently. ${ }^{20}$

Education is human maturity both intellectually, emotionally, and spiritually and will influence the future of state, nation and religion students, must be programmed, systematic, integrated and integral. ${ }^{21}$

From some of these meanings, it can be concluded that education is a process of guidance carried out by adults consciously on children to be able to live properly according to the demands of the times. As a process of guidance, education is an activity carried out in a planned and systematic manner. The culprit is someone or an institution (institution) known as family as informal education, school or madrasa as a formal education institution, and majelis ta'lim and other activities in the community as nonformal education. The object is of course students who need guidance or guidance. This activity is carried out based on a purpose of guidance or guidance which is carried out in a certain way in certain situations and environments. ${ }^{22}$

The correct education is as confirmed by Imam Al-Ghazali, according to him, "true education is a means to get closer to Allah. Education also leads people to reach the life of happiness in the world and the hereafter". ${ }^{23}$

According to Shaykh Abu Bakr Al-Jaziri Tauhid in Arabic is masdar from wahhada, yuwahhidu Tauhid means to make one, unite and negate numbers from it. While the term Tawhid in terms of negating the equivalent of the essence of Allah, in its nature and deeds, and denying allies in worshiping and worshiping it. $^{24}$

In another definition the notion of Tawhid is one's belief in the truth of the oneness of Allah, not associating with anything. ${ }^{25}$ Whereas Tauhid is literally "unifying" or

\footnotetext{
${ }^{17}$ Asep Sapa'at, Stop Being a Teacher, (Jakarta: Ladder Library, 2012), p. 276.

${ }^{18}$ Ngalim Purwanto, Theoretical and Practical Education Science, (Bandung: Remaka Karya, 2005), p. 1.

${ }^{19}$ Abuddin Nata, Philosophy of Islamic Education, (Jakarta: Primary Media Style, 2015), p.

${ }^{20}$ Azyumardi Azra, Islamic Education, Tradition and Modernization towards the New Millennium, (Jakarta: Logos, cet. II, 2010), p. 3.

${ }^{21}$ Qiqi Yuliati Zakiyah and A. Rusdiana, Value Education and Theory and Practice Study in schools, (Bandung: Loyal Library, 2014), p. 146.

${ }^{22}$ Zainul Bahri, Tawhid Education Program in the National Education System (Postgraduate Thesis of UIN Suska Riau PAI Study Program, 2018), p. 16

${ }^{23}$ Asrorun Niam Soleh, Reorientation of Islamic Education. (Jakarta: Elsas, 2016), p. 57.

${ }^{24}$ Syaikh Abu Bakar Al-Jaziri, Akidah Mu'min, Tarj. Asmuni Solihan Zamakhsyari, (Jakarta: Reader Al-Kautsar, 2012), p. 71.

${ }^{25}$ Rois Mahfud, Al-Islam (Islamic Education), (Jakarta: Erlangga, 2011), p. 13.
} 
"impinging" as a technical term in the word Tauhid which is intended as a notion of "God Almighty or more simply understanding" the supreme God "(monotheism). ${ }^{26}$

Al-Faruqi argues that Tawheed is the essence and core of Islamic teachings and also the general view of the reality of the truth of space and time, as well as history and human destiny, as philosophy and a view of life. In addition to that, Tauhid also has implications in the history of knowledge, philosophy, ethics, social, community, economic family, and aesthetics. In line with the views of Muhammad Iqbal, Al-Faruqi argues that Islam is relevant to all aspects of life thinking and being. Therefore, in every movement of his life, humans must conform and not deviate from the teachings of the Tawheed of Islam. According to C.A. Qadir, knowledge in the west has become a problem, because it has lost its true purpose. Therefore, it needs to be made aware that the education returns to a culture of Islamic knowledge and education that has superior characteristics. This effort is in line with what was stated by Al-Faruqi with the Islamization of science, so that science is in harmony with the teachings of Tawheed and Islamic teachings. ${ }^{27}$

From this explanation, it can be concluded that Al-Faruqi's view of Tawheed is the thing that underlies his thinking and steps, where Tawhid is the essence of Islamic teachings and becomes the principle of all movements of human life, and the only thing that can bring progress, because Islam in accordance with the circumstances and all ages. $^{28}$

Thus it can be analyzed that Tawheed education, human beings will become "dehumanist" non-human servants, then mutual love will arise, please help, give more wealth to those in need, always be alert to the deception of the world and human beings, and can simple (zuhud) and a heart of heart and so on. In addition, Tawhid education is an attempt to reveal or actualize other potentials possessed by humans, namely nature. One human nature is religious nature, therefore Tauhid education is more directed at developing one's religious nature as a Tauhid man. In other words, Tawhid education is an effort to change human behavior based on the teachings of Tawheed in life through guidance, teaching, and training based on belief only in Allah alone. ${ }^{29}$

\section{National Education System}

According to Sunarya, National Education is an educational system that stands on a foundation and imbued by the philosophy of life of a nation and its purpose is to serve the national interests and ideals of the nation. Meanwhile, the Ministry of Education and Culture formulates that national education is an effort guiding Indonesian citizens to become Pancasila, which is personal, based on the community's divine awareness and able to cultivate the surrounding environment. In the Republic of Indonesia's Law No. 2

\footnotetext{
${ }^{26}$ Nurcholish Madjid, Islamic Doctrine and Civilization A Critical Study of the Problems of Security, Humanity, and Kemodrenan, (Jakarta: Paramadina, 2010), p. 72-73.

${ }^{27}$ Norlaila "Thought of Ismai Raji Al-Faruqi Islamic Education". Al-Banjari, Scientific Journal of Islamic Sciences Vol. 7, No. 1, January 2008. Banjarmasin: Postgraduate Program of the State Islamic Institute of Antasari Banjarmasin. p. 36-39.

${ }^{28}$ Zainul Bahri, Tawhid Education Program in the National Education System (Postgraduate Thesis of UIN Suska Riau PAI Study Program, 2018), p. 21

${ }^{29}$ Zainul Bahri, Tawhid Education Program in the National Education System, p. 22

Indonesian Journal of Islamic Education Studies (IIIES)

Volume 2, Nomor 1, Juni 2019
} 
of 1989 concerning the National Education System in Chapter I Article 2 reads: National Education is education rooted in the culture of the Indonesian nation and based on Pancasila and the 1945 Constitution. This basis can be seen from paragraph 4 of the 1945 Constitution Chapter XIII Article 31. ${ }^{30}$

Based on Law No. 20 of 2003 concerning the National Education System, that education is a conscious and planned effort to create a learning atmosphere and learning process so that students actively develop their potential to have religious spiritual strength, self-control, personality, intelligence, noble character, and the necessary skills himself, society, nation and state. ${ }^{31}$ Whereas National Education is education based on Pancasila and the 1945 Constitution of the Republic of Indonesia which is rooted in religious values, Indonesian national culture and responsive to the demands of changing times. The national education system is the whole component of education that is interrelated in an integrated manner to achieve national education goals. ${ }^{32}$

\section{Methods}

The type of research used in writing this thesis is literature research literature (library research). This research was conducted by collecting data on "Tawhid Education Values in the National Education System". In addition, this study is also a descriptivequalitative study. Qualitative research is understood as research whose findings are not obtained through statistical procedures or other forms of calculation. ${ }^{33}$

To obtain the data needed, the author uses literature studies, literature studies (library research) ${ }^{34}$ namely by conducting a careful study of the literature relating to the subject matter being discussed. ${ }^{35}$ In this study, the primary source is the National Education System Law No. 20 of 2003.

Secondary sources are sources taken from other sources that are not obtained from primary sources (Anwar, 2008: 91). The secondary data sources in this study are: 1). Shaykh Shalih Bin Fauzan Al-Fauzan, 2014, Kitab Tauhid. Happened. Agus Hasan Bashori, Jakarta: Darul Haq. 2). Moh. Haitami Salim, 2013, Religious Education in the Family, Jogjakarta: Ar-Ruzz Media. 3). Fuad Ihsan, 2008, Basic Education Basics, Jakarta: Rineka Cipta. As well as books relating to and relevant to the problems in this proposal. Furthermore, through library research methods, the steps taken are reading, understanding and analyzing books, both in the form of Tawheed books and other sources related to existing problems, then analyzed.

The data analysis technique in this study uses content analysis techniques. Content analysis / content analysis is research that is in-depth discussion of the contents of a

\footnotetext{
${ }^{30}$ Fuad Ihsan, Basic Education Base, (Jakarta: Rineka Cipta, 2010), p. 107-108.

${ }^{31}$ Budi Wahyono, "Definition and Basics of the National Education System", http://www.pendidikanekonomi.com/2012/12/definisi-dan-dasar-sistem-pendidikan.html, (accessed on July 27, 2018, 08.08 WIB).

${ }^{32}$ Zainul Bahri, Tawhid Education Program in the National Education System, p. 35

${ }^{33}$ Anslem Strauss and Juliet Corbin, Basics of qualitative research: grounded theory procedures and techniques, translated by Muhammad Shodiq and Imam Muttaqien, Basics of Qualitative Research on Steps and Data Theoretical Techniques, (Yogyakarta: Student Library, 2017), p. 4.

${ }^{34}$ Sutrisno Hadi, Research Methodology, (Yogyakarta: Andi Offset, Vol. 1, 2009), p. 9.

${ }^{35}$ Nasution, Scientific Research Research Method, (Jakarta: Bumi Aksara, 2011), p. 150.
} 
written information or printed in the mass media. ${ }^{36}$ Noeng Muhadjir also stated that content analysis is a scientific analysis of the contents of a communication message. Technically content analysis includes classification of signs, using criteria as a basis for classification, and using analytical techniques to make predictions. ${ }^{37}$ Therefore the analysis in this study includes discussing, analyzing, classifying, and describing in depth about Tawhid Education Values in the National Education System.

\section{Results and Discussion}

\section{Tawhid Education Values in the National Education System}

\section{a. Chapter II Article 3 concerning National Education Objectives}

The values of Tawhid education contained in the first National education system are found in its objectives. So to explain it must begin with a description of the objectives of National education, namely: "Faith and piety are one of the characteristics of Indonesian people as a whole to be achieved through the National education system. In Law No. 20/2003 article 3 stated: National education aims to develop the potential of students to become human beings who believe and fear God Almighty, have noble character, are healthy, knowledgeable, capable, creative, independent, and become citizens of a democratic and responsible country. ${ }^{38}$

Thus, the values of Tawheed education lie in the first goal, namely to become human beings who believe and fear the Almighty God. Because the most important faith and piety are to be achieved through the National education system. Therefore, education should range between two dimensions, namely values, namely divine values and human values. First, the Divine value in the language of the Qur'an, this dimension of divine life is also called the soul of rabbaniyah or ribbyah. And if you try to specify what are the real manifestations or substance of the divine soul, then you will get very important personal religious values that must be instilled in each person, especially students. The activity of instilling these values will actually be the core of educational activities. Among the very basic values, namely: faith and piety, faith is a spiritual attitude that is full of trust in God. Whereas tawa is an attitude that is fully aware that God is always watching over all creatures on this earth, and trying to do only something that Allah cherishes by avoiding or guarding himself from something that is not pleasing to Him. Second, the value of Islamic education cannot be understood in a limited way only to teaching. Therefore the success of education for students is not sufficiently measured only in terms of how far the students master things that are cognitive in nature. What is more important for Muslims is how far embedded human values are manifest in behavior and the mindfulness of everyday character will give birth to nobility and morality of Al-Karimah. The close link between piety and nobility is the same as the relationship between faith and virtuous charity, prayer, and charity ". 39

\footnotetext{
${ }^{36}$ Noeng Muhajir, Qualitative Research Methodology, (Yogyakarta: Rake Sarasin, 3rd edition, cet. 7th, 2016), p. 69. 2015), p. 59.

${ }^{37}$ Eriyanto, Discourse Analysis: Introduction to Media Text Analysis, (Yogyakarta: Lkis, cet. 5,

${ }^{38}$ National Education Ministry Compilation Team, (Law of the Republic of Indonesia), p. 6.

${ }^{39}$ Abdul Majid and Dian Andayani, Character Education, p. 92-93.
} 


\section{b. Chapter V Article 12 Paragraph 1 point A concerning Students}

Basically the learning process is closely related to the four elements, namely: educators, students, subject matter, and teaching systems. In achieving the desired educational goals, educators and students are two elements that are interdependent. The position of students in the frame of education is both the subject and the object. Seeing the complexity of the position of students is very important. So in the learning process students should be equipped with sufficient basic skills. In addition, in its achievement, of course, it should not be deviated from the corridor of the order of the Lord's teachings, such as: obedience, truth, honesty, justice, benefit, and so forth. As already compiled in Law No. 20 of 2003 that: "Every student in each education unit has the right: get religious education in accordance with the religion he adheres to and is taught by religious educators". 40

The religious education is related to Tauhid which aims to make students become human beings who believe and fear God Almighty. In order for this to be achieved, religious education must be given to students in educational institutions whether formal, non-formal, and informal must be religious education in accordance with the religion of the students. So that it can be seen in formal educational institutions, especially during religious studies, the class is separated between students of different religions. In addition, it is also important that educators who teach it must also be religious educators with these students, so they synchronize and connect the lessons delivered. Thus creating a conducive learning process. $^{41}$

\section{c. Chapter X Article 36 Paragraph 3 point A about the curriculum}

The curriculum as one component of education is very instrumental in delivering to the expected goals. For this reason, the curriculum is the main force that influences and shapes the learning process. Errors in the preparation of the curriculum will lead to failure of education and tyranny of students.

As curriculum becomes very important in an educational process as the main reference for achieving educational goals in general. ${ }^{42}$ If further analyzed, the curriculum in Law No. 20 of 2003 is essentially the same as the Islamic education curriculum. namely: "The curriculum is prepared in accordance with the level of education within the framework of the Unitary State of the Republic of Indonesia by taking into account: Increasing faith and piety". ${ }^{43}$

So that it can be seen that the curriculum contained in Law No. 20 of 2003 has similarities with the Islamic education curriculum in its achievements or the first thing to be considered. That is about increasing faith and piety to God Almighty.

\section{Relevance of National Education System Law No. 20 of 2003 in Strengthening Tawheed Education Values}

\section{a. Chapter II Article 3 concerning National Education Objectives}

\footnotetext{
${ }^{40}$ National Education Ministry Compilation Team, (Law of the Republic of Indonesia), p. 8-9.

${ }^{41}$ Zainul Bahri, Tawhid Education Values in the National Education System, p. 67

${ }^{42}$ Lias Hasibuan, Curriculum and Educational Thought, (Jakarta: GP Press, 2010), p. 20.

${ }^{43}$ National Education Ministry Compilation Team, (Law of the Republic of Indonesia), p.18.
} 
The relevance of the National Education System Law No. 20 of 2003 in strengthening the values of Tawhid education can be seen from the first objective of the National Education System Law that it is positioned to make people who believe and fear God the Almighty. This indicates that the National Education System Law has a strong relevance in order to strengthen the values of education in Tawhid. As has been compiled in Law No. 20 of 2003. Namely: "Faith and piety are one of the characteristics of Indonesian people as a whole to be achieved through the National education system. In Law No. 20/2003 article 3 stated: National education aims to develop the potential of students to become human beings who believe and fear God Almighty, have noble character, are healthy, knowledgeable, capable, creative, independent, and become citizens of a democratic and responsible country ". 44

It is even more obvious that the purpose of Islamic education is the same as the aim of National education, which according to the Ministry of Education's PUSKUR the aim of PAI is to grow and improve the faith and piety of students through the provision and fertilization of knowledge, appreciation, so that Muslims continue to develop in terms of faith and devotion to Allah SWT. This means that both positions the values of Tawheed education as the first and foremost goal in education. Because the goal is actually the dominant thing in education. Thus, to achieve all that there are at least a number of things that must be introduced to students through the subject matter taught in each field of science namely, introducing them, that human beings individually are God's creatures who have responsibility in life, human beings social includes members of the community and has responsibilities where it is, this universe is God's creation and invites students to understand the wisdom of Allah creating it and for preserving it. Introducing the creator of the universe and encouraging him to worship Him. This pointer will lead someone to the goal of National education. ${ }^{45}$

In connection with that, this relevance aside from the objectives stated in the National education goals has to do with the competence and qualifications of the AlQur'an educators which essentially have implications especially for the purpose of National education. Adequate competence and qualifications of the Qur'anic educators will able to integrate the sciences that are in the Qur'an with the actualization and development of modern science with an integrated that can be widely useful and have positive implications for the advancement of noble human civilization. Adequate competence and qualifications of Al-Qur'an educators will be able to boost the quality of National education, so as to be able to compete competitively, regionally and globally. ${ }^{46}$

Adequate competence and qualifications of Al-Qur'an educators will be able to present the face of Islam which is Rahmatallil'alamin, as an expression of the contents and values of the teachings of the Qur'an. As a living guide of the Qur'an, it must be read, studied, understood, guided and practiced in everyday life, because in the Qur'an there are instructions, explanations and even differences in all things. Based on the commentator, it can be said that the Qur'an is a guide for humans for salvation and

\footnotetext{
${ }^{44}$ National Education Ministry Compilation Team, (Law of the Republic of Indonesia), p. 6.

${ }^{45}$ Zainul Bahri, Tawhid Education Values in the National Education System, p.75

${ }^{46}$ Zainul Bahri, Tawhid Education Values in the National Education System, p. 79
} 
happiness in the world and the hereafter. ${ }^{47}$ Thus so that this can be achieved by someone, of course someone must believe and fear God Almighty in accordance with the objectives of National Education No. 20 of 2003.

True happiness can be obtained by everyone. All humans surely want a life and a happy life both in joy and sorrow, hard or happy. Happiness is a necessity to be realized. As long as humans restore and follow their nature as a servant, humans are able to achieve happiness. That is why the most important people in a family are required to be able to play their respective roles, especially guarding themselves to be able to achieve happiness and avoid the humiliation of life in the world and in the hereafter. The success or failure of education in children is not only the influence of parents, but also influenced by schools, playmates and the community. Focusing on the role of educators in family education is the beginning of the success of national education. The community is essentially a collection of families. If families are in good condition, logically the community environment will be good for children's education. this will certainly improve the quality of education in schools and at the same time be able to realize national education. ${ }^{48}$

\section{b. Chapter V Article 12 Paragraph 1 point A concerning Student Rights}

Religious education is a subsystem of the national education system, the position of religious education as a subsystem in national education can be seen in formal and substantial jurisdiction, starting from the Republic of Indonesia 1945 Constitution, Republic of Indonesia Law No. 20 of 2003, to the Republic of Indonesia regulation No. 55 In 2007 concerning religious and religious education. As stated in Law No. 20 of 2003 concerning students. Namely, each student in each education unit has the right to receive religious education in accordance with the religion he adheres to and is taught by religious educators. ${ }^{49}$

From this brief description, it is clear that Law No. 20 of 2003 has relevance in strengthening the values of Tawheed education, namely by putting the right of the first student entitled to religious education in accordance with the religion adhered to and taught by religious educators, this, demonstrating that the importance of religious education in life, because this religious education is related to Tawheed which is the basis of all other education. Therefore, by putting the rights of the first learners to get religious education, this is what will deliver these students to the objectives of National education to be human believers and fear God Maha Esa. ${ }^{50}$

In the 1945 Constitution of the Republic of Indonesia it is stated that every citizen has the right to education, and every citizen is obliged to attend basic education which the government is obliged to finance. The government seeks and organizes a national education system, which enhances the faith and piety and noble character in order to

\footnotetext{
${ }^{47}$ Bisri Musthafa, Al-Qur'an Educator Competence (Study of Minister of Religion Regulation No. 13/2014 Article 50 Paragraph 5 About Al-Qur'an Educators and Its Implications for Eradicating Qur'anic Illiteracy in Indonesia), Pekanbaru: Summary of Dissertation, 2017), p. 28-29.

${ }^{48}$ Zainul Bahri, Tawhid Education Values in the National Education System, p. 83

${ }^{49}$ National Education Ministry Compilation Team, (Law of the Republic of Indonesia), p.6.

${ }^{50}$ Zainul Bahri, Tawhid Education Values in the National Education System, p. 85
} 
educate the nation's life, which is regulated in the Law. Furthermore, the government promotes science and technology by upholding religious values and national unity for the advancement of civilization and human welfar. ${ }^{51}$

Although textually, religious education is not mentioned in the 1945 Law, but substantially there are several things concerning religious education: 1) that among the objectives of national education is to increase faith and piety and noble character, 2) that the government advances science and technology by upholding religious values and national unity for the advancement of civilization and the welfare of mankind. Based on these substantial values, increasing faith and piety, noble character and upholding religious values and national unity for the advancement of human civilization, there is no way that can be achieved without the process of religious education. Likewise in the Republic of Indonesia Law No. 20 of 2003 in Chapter 2, Article 3, relating to the functions and objectives of National Education, there are several key statements in the article relating to the importance of religious education: "developing abilities and forming a character and civilization that are dignified, aiming for the development of potential students in order to become a man of faith and piety to the One God, noble, healthy, knowledgeable, capable, creative, independent, and a democratic and responsible citizen. ${ }^{52}$

This means that the four key statements in this article actually show the importance of the position of religious education in the national education system, which most of the functions of national education are a function of religious education. Therefore the four key statements are actually the domain of religious education in a broad sense, in other words it can be said that the core of national education is religious education. Thus it can be understood why then juridically the existence of religious education in the National education system is reinforced by the inclusion of articles contained in the Republic of Indonesia's Law No. 20 of 2003 concerning this National education system. ${ }^{53}$

Explicitly, it can be seen in chapter 4 regarding the pathway, level and type of education, ninth part, religious education, in article 30 stated: 1) religious education is organized by the government or community groups of religious followers in accordance with the laws and regulations, 2) education religion serves to prepare students to become members of the community who understand and practice the values of religious teachings and become experts in the field of religion, 3) religious education can be held on formal, non-formal and informal education, 4) religious education in the form of diniyah education, pesantren and other similar forms, 5) provisions concerning religious education as referred to in paragraphs 1,2,3,4 are further regulated by government regulations. Furthermore, in the RI government regulation No. 55 of 2007 concerning religious education and religious education, also explained that the function of religious education is to shape Indonesian people who are faithful and pious to the Almighty God and have a noble character and are able to maintain peace and harmony in inter-relations

${ }^{51}$ National Education Ministry Compilation Team, (Law of the Republic of Indonesia), (Jakarat: Diknas, 2010), p. 9, 53-54, and 77-78

${ }^{52}$ Munzir Hitami, Conceptualizing, (Pekanbaru: UIN Press, 2010), p. 34-36.

${ }^{53}$ Zainul Bahri, Tawhid Education Values in the National Education System, p. 99 
and inter-religious relations. In addition, religious education aims to develop the ability of students to understand, appreciate and practice religious values that harmonize their mastery in science, technology and art. ${ }^{54}$ Thus, it is clear that religious education is an integral part of the national education system. And also religious education can be held formally, formally, and informally. ${ }^{55}$

\section{c. Chapter X Article 36 Paragraph 3 point A about the curriculum}

According to Muhammad Ali the curriculum is not sufficiently understood as a lesson plan, because the educational activities and processes are broad in scope. The curriculum must be understood as a plan of learning experience, as a plan of educational goals to be achieved, and as a plan for learning opportunities (Ali, 2012: 2-8). Regarding the definition of the curriculum the author can conclude that the curriculum is an educational activity and experience that is designed, programmed and organized by educational institutions both inside and outside the school with a view to achieving the objectives. As written in Law No. 20 of 2003 that: The curriculum is prepared in accordance with the level of education within the framework of the Unitary State of the Republic of Indonesia by taking into account: Increased faith and piety (Composer: 18).

This description is in accordance with the process of Islamic education, the curriculum is an educational tool that is more concerned with the future life interests of worldly and spiritual value, because in its preparation oriented to the development of divine values, social values and the surrounding environment, so that the curriculum presented can play a role in preparing participants students in carrying out their functions as caliphs and also making people who believe and fear the Almighty God. This description shows that Law No. 20 of 2003 has a connection in strengthening the values of Tawheed education, which is the first increase that must be achieved by compiling the curriculum is to increase faith and piety to the Almighty God. This is in accordance with Imam Al-Ghazali's view of the curriculum that in compiling the lesson curriculum gives more special attention to the science of religion and ethics. ${ }^{56}$

This is in accordance with the National Education System Law outlined in the 1945 Constitution of the Republic of Indonesia, article 4 has provided a balance between increasing faith and piety and noble character in order to educate the life of the nation. Pictured in the functions and objectives of national education, the National Education System Law has thus provided a balance between faith, science and charity (pious). This is not only reflected in the functions and objectives of National education, but also reflected in the curriculum in which increasing faith and piety, noble character, intelligence, science, technology, art and so on are combined into one. ${ }^{57}$

Thus it can be understood that the functions, goals and curriculum of the national education are in line. So that with all this achieved the objectives of national education in accordance with those already compiled in Law No. 20 of 2003. In the description also shows that Law No. 20 of 2003 has a connection in strengthening the values of Tawheed

\footnotetext{
${ }^{54}$ Moh. Haitami Salim, Religious Education, (Jakarta: Graha Pustaka, 2010), p. 31.

${ }^{55}$ Zainul Bahri, Tawhid Education Values in the National Education System, p. 101

${ }^{56}$ Abuddin Nata \& Fauzan, Education, p. 190-191

${ }^{57}$ Zainul Bahri, Tawhid Education Values in the National Education System, p. 107
} 
education, namely to continue to position and prioritize the increase of faith and piety at the position of the initial achievement rather than the increase of others, the same as the educational goals and rights of students. So it seems clear that it has a strong connection in strengthening the values of Tawheed education. ${ }^{58}$

In connection with taqwa as the orientation of the National education system, it is stated in the goals, rights of students, and curriculum. then there are some Hadiths that explain one of the piety which means: Abu Hurairah Ra. Narrates that the Prophet was asked about who was the most noble person. He replied, "the most fearful person is Allah SWT." (HR.Al-Bukhari).

This hadith shows that the most noble man is the highest level of piety. The attitude of piety overcomes all indications of other dignity. The symbols of modernity and the well-being of a person cannot defeat the attitude of piety. it means that even though someone has the skills to use the latest technology that has abundant wealth. But if he does not fear Allah, then he really cannot be included in the most noble category. Therefore, if the educational process is intended to enhance the dignity and dignity of human life, then something that must be done is an effort to increase piety to Allah. all educational activities must refer to the formation of cautious attitudes and behavior. So the criteria of those who are cautious can be classified into three aspects, namely having a strong faith, doing good worship, and having noble character. Then the three behaviors contained in the term tawa. if it is agreed that the purpose of education is to form a righteous person, then all educational activities must be directed towards achieving such attitudes and behavior. ${ }^{59}$

Thus the aforementioned Hadith, in fact the Prophet Muhammad motivated the companions to be a cautious person by placing Muttaqin in the most honorable position. This motivation is supported by the National education system in Indonesia, where all citizens are led to achieve taqwa qualifications in all levels, paths, types and processes of education they follow. ${ }^{60}$

Then related to the faith there are Hadith which means: "Sufyan bin Abdullah AtsTsaqafi related that he said to the Messenger of Allah," O Messenger of Allah, tell me something about Islam that I will not ask again after you. "The Prophet said. "Say, I have faith in Allah. Then set your stand ". (Al-Hadith).

This hadith shows that faith in Allah and istiqamah with the recognition of faith is something that is sufficient and sufficient for a Muslim. Therefore, educators must strive so that students have a strong and firm faith in carrying out the demands of the faith. All educational activities are directed towards the formation of believers. so that the criteria of those who believe is one of them is to shake his heart when he hears the name of Allah. ${ }^{61}$

Thus, if a believer is believed to be a person who is glorified and privileged by God in the world and in the hereafter, then all processes of Islamic education should be

\footnotetext{
${ }^{58}$ Zainul Bahri, Tawhid Education Values in the National Education System, p. 109

${ }^{59}$ Bukhari Umar, Hadith Tarbawi: Education in the Islamic Perspective, (Jakarta: Amzah, 2015), p. $29-31$.

${ }^{60}$ Zainul Bahri, Tawhid Education Values in the National Education System, p. 111

${ }^{61}$ Bukhari Umar, Hadith Tarbawi: Education in the Islamic Perspective, p. 32-34 
directed towards achieving that degree. This is possible if every educator attempts to carry out various educational activities that have the potential to bring students to the quality of good faith. More explicitly, educators need to enter your professional qualifications in the formulation of educational goals that they do. ${ }^{62}$

\section{Conclusion}

Based on the discussion about Tawhid Education Values in the National Education System. So it can be concluded, "That the Tawhid Education Values contained in the National Education System Law No. 20 of 2003. There are goals in National education, rights of students, and curriculum. The Tauhid Education Values contained in the National Education Goals according to the National Education System Law No. 20 of 2003, are very dominant, need to be elaborated on the initial objectives of faith and piety covering all components of education, especially religious education. because basically religious education in schools / madrasas aims to foster faith and piety, as well as national education goals. Then the Tawhid Education Values contained in the rights of students in each education unit according to the National Education System Law No. 20 of 2003, are inadequate and require comprehensive translation, need to be elaborated on first rights, namely getting religious education in accordance with the religion they adhere to and educated religion. And the values of Tawheed education contained in the National education curriculum according to the National Education System Law No. 20 of 2003, are very dominant, need to be elaborated on increasing faith and piety covering all components of education in order to develop a better national education curriculum ".

Relevance of National Education System Law No. 20 of 2003 in Strengthening Tawheed Education Values. Law No. 20 of 2003 considers that education is the first and foremost issue in order to build and improve the people. One of the points contained in it is Tawhid. This can be seen from the purpose of education. Because National education has the basic principles and objectives of education about the Aqeedah Tawheed and sees that everything comes only from one source from Allah, one of which is science. therefore, the imitation learning model, the approach to learning has the nuances of Tauhid faith, its orientation is towards strengthening faith and piety, and learning is also done with a spiritual approach. Thus the Tawheed faith which has been embedded in one's person must give birth to noble character. So the success of education is not only marked through cognitive mastery, but the main parameter is that one's attitude and behavior must reflect the faith and piety of Allah. Therefore, the Law on National Education System No. 20 of 2003 has relevance in strengthening the values of Tawheed education, namely, the first national education goal which is primarily believing and fearing the Almighty God, speaking of matters of faith and piety, of course discussing Tauhid, the national education's main purpose is to instill faith and piety towards the creator, learning in National education must not be separated from unity and faith. Then the relevance of Law No. 20 of 2003 in strengthening Tawheed education that by placing the rights of the first students entitled to religious education in accordance with the religion adhered to and

${ }^{62}$ Zainul Bahri, Tawhid Education Values in the National Education System, p. 117 
taught by religious educators, this, shows that the importance of religious education in life, because religious education is contained in Law No. 20 of 2003 is related to strengthening the values of Tawheed education which is the basis of all other education.

\section{References}

Abu, Shaykh, Bakar Al-Jaziri, Akidah Mu'min, Tarj. Asmuni Solihan Zamakhsyari, (Jakarta: Reader Al-Kautsar, 2012)

Ali, Muhammad, Curriculum Development in Schools, (Bandung: Sinar Baru, 2002), Cet. II

Anwar, Saifuddin, Research Methodology, (Yogyakarta: Offset Student, 2008)

Azra, Azyumardi, Islamic Education, Tradition and Modernization towards the New Millennium, (Jakarta: Logos, cet. II, 2010)

Wisdom, Tauhid values in Asma'Wa Al-Shifat according to Salih Bin Fauzan Bin Abdullah Al-Fauzan (Study in Kitab Al-Tauhid Li Al-Shaff Al-Awwal Al-Ali Fi Al-Ma'ahid Al-Islamiyah), (Riau: Sultan Syarif Kasim State Islamic University Riau, 2011).

Bahri, Zainul, Tawhid Education Values in the National Education System (Postgraduate Thesis of UIN Suska Riau PAI Study Program, 2018).

David, Muhammad, Ali, Islamic Education, (Jakarta: PT Raja Grafindo Persada, 2016)

Eriyanto, Discourse Analysis: Introduction to Media Text Analysis, (Yogyakarta: Lkis, cet. 5, 2015)

Hadi, Sutrisno, Research Methodology, (Yogyakarta: Andi Offset, Jil. 1, 2009)

Hasan, Hafiedh, National Education System Based on Tawheed Science (STIT Pemalang, Islamic education study program)

Hasibuan, Lias, Curriculum and Educational Thought, (Jakarta: GP Press, 2010)

Herimanto, Basic Social and Cultural Sciences, (Jakarta: PT. Bumi Aksara, 2010)

Ihsan, Fuad, Basic Basic Education, (Jakarta: Rineka Cipta, 2008), p. 107-108.

Lestari, S. \& Ngatini, Contextual Islamic Education, (Yogyakarta: Student Library, 2010)

Mahfud, Rois, Al-Islam (Islamic Education), (Jakarta: Erlangga, 2011)

Majid, Abdul and Dian Andayani, Islamic Perspective Character Education, (Bandung: PT Remaja Rosdakarya Offset, 2012)

Majid, Abdul, Tawheed Based Education: Khutbah 'Idul Fitri 1 Syawal 1423 H./2002 M.

Majid, Nurcholis, Islamic Doctrine and Civilization A Tela'ah Critical About Security, Humanitarian, and Kemodrenan Problems, (Jakarta: Paramadina, 2010) 
Muhajir, Noeng, Qualitative Research Methodology, (Yogyakarta: Rake Sarasin, 3rd edition, cet. 7th, 2006)

Muhmidayeli, Educational Philosophy, (Bandung: PT Refika Aditama, cet. 2nd, 2013)

Mujib, Abdul and Yusuf Mudzakkir, Islamic Education, (Jakarta: Kencana Prenada Media, 2016)

Mujib, Abdul, Fitrah and Islamic Personality: A Psychological Approach, (Jakarta: Darul Falah, 2009)

Mulyana, Rahmat, Articulating Value Education, (Bandung: Al-Fabeta, 2011)

Musthafa, Bisri, Al-Qur'an Educator Competence (Study of Minister of Religion Regulation No. 13/2014 Article 50 Paragraph 5 About Al-Qur'an Educators And Its Implications For Eradicating Al-Qur'an Literacy In Indonesia), Pekanbaru: Dissertation Summary, 2017)

Nashih, Abdullah, Ulwan, Tarbiya Al-Awlad Fil Al-Islam (Child Education in Islam), (Jakarta: Library of Amani, 2017)

Nasution, Scientific Research Research Method, (Jakarta: Bumi Aksara, 2011)

Nata, Abuddin, Philosophy of Islamic Education, (Jakarta: Primary Media Style, 2015)

Niam, Asrorun, Soleh, Reorientation of Islamic Education. (Jakarta: Elsas, 2016)

Norlaila "Thought of Ismai Raji Al-Faruqi Islamic Education". Al-Banjari, Scientific Journal of Islamic Sciences Vol. 7, No. 1, January 2008. Banjarmasin: Postgraduate Program of the State Islamic Institute of Antasari Banjarmasin

Compiler, Team, National Education Ministry, (Law of the Republic of Indonesia)

Compiler, Team, National Education Ministry, Law of the Republic of Indonesia No. 20 of 2003 concerning National Education System, (Bandung: Umbara Citra Publishers, 2007)

Pokja, Akademik, Tauhid, (Yogyakarta: Academic Working Group UIN SUSKA, 2015)

Purwanto, Ngalim, Theoretical and Practical Education Science, (Bandung: Remaka Karya, 2005)

Romli, Usup, Tawheed Education Model in Regelius Employers' Family (Descriptive Study in the Family of H. Abdurrahman Yuri R.G". Tarbawi Journal Vol. 1, No. 1, March 2012

Salahuddin, Anas and Irwan Alkrienchiechie, Character Education, Education Based on Religion and National Culture, (Bandung: Librarian Setia, 2013)

Saleh, M., Faith Education at the Age of Children: Psychological Review, (Undergraduate Thesis in Islamic Education UIN Library Sunan Kalijaga Yogyakarta, 2010) 
Sapa'at, Asep, Stop Being a Teacher, (Jakarta: Ladder Library, 2012),

Strauss, Anslem and Juliet Corbin, Basics of qualitative research: grounded theory procedures and techniques, translated by Muhammad Shodiq and Imam Muttaqien, Basics of Qualitative Research on Steps and Data Theoretical Techniques, (Yogyakarta: Student Library, 2007)

Thoha, HM. Chabib, Kapita Selekta Islamic Education, (Yogyakarta: Student Library), 2006)

Umar, Bukhari, Hadith Tarbawi: Education in the Islamic Perspective, (Jakarta: Amzah, 2015)

1945 Constitution of the Republic of Indonesia (TK: Tp, 2010)

Wahyono, Budi, Definition and Basics of the National Education System, http://www.pendidikanekonomi.com/2012/12/definisi-dan-dasar-sistempendidikan.html, (accessed on July 27, 2018, 08.08 WIB).

Yuliati, Qiqi, Zakiyah and A. Rusdiana, Value Education and Theory and Practice Studies in schools, (Bandung: Faithful Library, 2014) 